\title{
PENGARUH METODE EKSPERIMEN TERHADAP HASIL BELAJAR MATA PELAJARAN IPA MATERI PERUBAHAN ENERGI BUNYI MELALUI PENGGUNAAN ALAT MUSIK DI KELAS IV SEKOLAH DASAR
}

\author{
Hani Septiani \\ SD Negeri Sokaraja Lor, Banyumas, Indonesia \\ Email: haniseptiani1993@gmail.com
}

\begin{abstract}
Commonly, science teaching and learning was still focused on the teacher. Teacher gave less direct experience to the students like experiment and observation activities. Commonly, the science learning still used presentation method and giving exercises with questions. Students do not have the chance to have experiments or observation. The innovation in theaching learning can apply one of the teaching method, namely by experiment method, the problem formulation of this research was whetheror not there was an effect of the experiment method toward the students'learning outcome for the fourth graders of elementary school. The learning result observed consisted of three aspect: cognitive, affective, and psychomotor aspects. This reserach is a quantitative research with an experiment design. The subject of the research was the fourth graders of elementary school consisting of two classes, the students of class IVA with 19 students as the control class, and the students of class IVB with 20 students as the experiment class. The technique of collecting the data was by posttest for the cognitive aspect, hard work questionnaire for the affective aspect, and work performance for the psychomotor aspect. The material used in this reserach was all in the topic of energy changes through the use of instrumental music. The data gained was then analyzed by Mann Whitney test. Based of the calculation, it could be concluded that three was an effect of experiment method toward the students' science learning outcome on cognitive and psychomotor aspects, however it had no effect on the students' science learning outcome on the affective aspect of the fourth graders of elementary school.
\end{abstract}

Keywords : Learning Outcome, Science, Experiment Method

\begin{abstract}
Abstrak. Pada umumnya pembelajaran IPA di SD masih berpusat pada guru. Guru kurang memberikan pengalaman langsung kepada siswa seperti kegiatan eksperimen dan pengamatan. Pada umumnya pembelajaran IPA masih menggunakan metode ceramah dan pemberian latihan dengan soal-soal. Siswa tidak diberi kesempatan untuk melakukan pengamatan maupun eksperimen. Inovasi dalam pembelajaran dapat menerapkan salah satu metode pembelajaran yaitu dengan menggunakan metode eksperimen Rumusan masalah pada penelitian ini adalah apakah ada pengaruh metode eksperimen terhadap hasil belajar IPA siswa kelas IV Sekolah Dasar. Penelitian ini dilaksanakan untuk mengetahui pengaruh metode eksperimen terhadap hasil belajar IPA siswa kelas IV Sekolah Dasar. Hasil belajar yang diteliti meliputi tiga aspek yaitu aspek kognitif, aspek afektif dan aspek psikomotor. Jenis penelitian yang akan dilaksanakan adalah penelitian kuantitatif dengan jenis penelitian eksperimen. Subyek penelitian ini yaitu siswa kelas IV Sekolah Dasar yang terdiri dari dua kelas yaitu siswa kelas IVA yang berjumlah 19 dan siswa kelas IVB yang berjumlah 20 siswa. Kelas IVB sebagai kelas eksperimen dan siswa kelas IVA sebagai kelas kontrol. Teknik pengumpulan data untuk aspek kognitif menggunakan pos tes, untuk aspek afektif menggunakan angket kerja keras, dan aspek psikomotor menggunakan unjuk kerja. Materi yang digunakan dalam penelitian mencakup materi perubahan energi bunyi melalui penggunaan alat musik. Data yang diperoleh kemudian dianalisis menggunakan uji Mann Whitney. Berdasarkan hasil perhitungan terdapat pengaruh metode eksperimen terhadap hasil belajar IPA aspek kogninif dan psikomotor, tetapi tidak memberikan pengaruh terhadap hasil belajar IPA aspek afektif siswa kelas IV Sekolah Dasar.
\end{abstract}

Kata Kunci : Hasil Belajar, IPA, metode eksperimen 


\section{PENDAHULUAN}

Proses belajar mengajar di Sekolah Dasar (SD) khususnya pada mata pelajaran Ilmu Pengetahuan Alam (IPA), seorang guru harus mampu melaksanakan kompentensi yang diwajibkan, standar kompetensi dan indikator harus dapat dicapai oleh siswa. Kompetensi dalam pelajaran IPA mutlak diperlukan agar kegiatan belajar mengajar berjalan secara kondusif dan dapat meningkatkan hasil belajar siswa. Kegiatan belajar mengajar yang terjadi di dalam kelas menuntut seorang guru untuk mampu menciptakan suasana belajar yang aktif, kreatif, kondusif, dan bahkan harus menyenangkan siswa, sehingga membuat mereka merasa nyaman dan betah belajar di dalam kelas. Proses pembelajaran di kelas dapat berjalan dengan baik sehingga dapat mendorong siswa untuk mendapatkan hasil belajar yang maksimal.

Hasil belajar meliputi tiga aspek yaitu aspek kognitif, afektif, dan psikomotor. hasil belajar siswa dapat dijadikan sebagai acuan dari keberhasilan dan ketercapaian siswa di dalam pembelajaran. Pembelajaran IPA di SD menekankan pada pemberian pengalaman belajar secara langsung melalui penggunaan dan pengembangan keterampilan proses dan sikap ilmiah. Hal tersebut memberikan tuntutan pada pembelajaran IPA agar menerapkan metode pembelajaran yang dapat mengarahkan siswa untuk melakukan proses ilmiah.

Pada umumnya pembelajaran IPA di SD masih berpusat pada guru. Metode pembelajaran yang diterapkan oleh guru kurang bervariasi sehingga proses pembelajaran IPA terkesan membosankan dan kurang menarik bagi siswa. Guru hanya memberikan materi-materi kepada siswa dan kurang memberikan pengalaman langsung kepada siswa seperti kegiatan eksperimen dan pengamatan. Pada umumnya pembelajaran IPA masih menggunakan metode ceramah dan pemberian latihan dengan soal-soal. Siswa tidak diberi kesempatan untuk melakukan pengamatan maupun eksperimen. Guru dituntut kreatif untuk mengadakan inovasiinovasi dalam pembelajaran, khususnya pembelajaran IPA.

Inovasi dalam pembelajaran dapat menerapkan salah satu metode pembelajaran yang dapat mengoptimalkan hasil belajar siswa. Salah satu metode pembelajaran yang mendukung terjadinya proses tersebut adalah metode eksperimen. Menurut Sagala (2010: 220) metode eksperimen adalah cara penyajian bahan pelajaran untuk siswa melakukan percobaan dengan mengalami untuk membuktikan sendiri sesuatu pertanyaan atau hipotesis yang dipelajari. Proses pembelajaran dengan metode eksperimen siswa diberi kesempatan untuk mengalami sendiri atau melakukan sendiri, mengikuti proses, mengamati suatu objek, menganalisis, membuktikan, dan menarik kesimpulan sendiri tentang suatu objek, keadaan, atau proses sesuatu.

Metode eksperimen mempunyai kelebihan yaitu siswa belajar dengan mengalami atau mengamati sendiri suatu proses atau kejadian, mengembangkan sikap berpikir ilmiah, dan memperkaya pengalaman dengan hal-hal yang bersifat objektif dan realistis. Metode eksperimen dapat diterapkan dalam pembelajaran IPA KD 8.4 menjelaskan perubahan energi bunyi melalui penggunaan alat musik. Siswa akan melaksanakan suatu percobaan pembuatan alat musik sederhana untuk mengetahui perubahan energi bunyi melallui penggunaan alat musik. Pada materi perubahan energi bunyi melalui penggunaan alat musik, siswa secara langsung membuat suatu alat peraga yang dapat memudahkan mereka untuk memahami materi tersebut. 
Berdasarkan latar belakang, peneliti tertarik untuk melakukan penelitian eksperimen untuk melihat pengaruh metode eksperimen terhadap hasil belajar IPA materi perubahan energi bunyi melalui penggunaan alat musik di kelas IV Sekolah Dasar. Penggunaan metode pembelajaran tersebut diharapkan dapat mengarahkan siwa unuk melakukan proses ilmiah.

\section{METODE PENELITIAN}

Metode yang digunakan dalam penelitian ini adalah metode eksperimen. Penelitian eksperimen ini menggunakan metode Randomized Subject, PretestPosttest Control Group Design. Desain penelitian ini terdapat dua kelompok yang masing-masing dipilih secara random. Kelompok pertama diberi perlakuan (X) dan kelompok yang lain tidak. Kelompok yang diberi perlakuan disebut kelompok eksperimen dan kelompok yang tidak diberi perlakuan disebut kelompok kontrol. Masing-masing dari kelompok mendapat pre test dan pos test.

Penelitian ini dilakukan di kelas IV SD Negeri Sokaraja Lor dengan jumlah populasi 39 siswa. Kelompok dalam penelitian ini adalah siswa kelas IVA dan IVB SD Negeri Sokaraja Lor. Semua siswa adalah homogen maka pengambilan sampelnya dipilih menggunakan teknik sampel acak untuk menentukan kelas eksperimen dan kelas kontrol. Sampel dalam penelitian ini adalah kelas IVA sebagai kelas kontrol dan kelas IVB sebagai kelas eksperimen. Instrumen penelitian menggunakan pos tes untuk mengetahui hasil belajar aspek kogitif, angket untuk aspek afektif, dan unjuk kerja untuk hasil belajar IPA aspek psikomotor. Metode analisis data menggunakan uji prasyarat yaitu uji homogenitas data. Setelah melakukan uji prasarat, langkah selanjutnya yaitu uji hipotesis dengan menggunakan uji Mann Whitney.

\section{HASIL DAN PEMBAHASAN Hasil Belajar IPA Aspek Kognitif}

Hasil penelitian menunjukkan ada pengaruh metode eksperimen terhadap hasil belajar aspek kognitif mata pelajaran IPA materi perubahan energi bunyi melalui penggunaan alat musik pada siswa kelas IV SD Negeri Sokaraja Lor. Hal ini dibuktikan dengan hasil perhitungan dengan menggunakan uji Mann Whitney untuk mengetahui pengaruh metode Eksperimen terhadap hasil belajar IPA aspek kognitif. Hasil uji Mann Whitney diperoleh $U_{\text {hitung }} \leq U_{\text {tabel }}$ atau $105 \leq 107$; sehingga $\mathrm{H}_{\mathrm{o}}$ ditolak dan $\mathrm{H}_{\mathrm{a}}$ diterima. Hasil perhitungan SPSS 16,0 juga membuktikan penolakan Ho dengan perolehan nilai signifikasi sebesar 0,016 yang lebih kecil dari 0,05. Lebih jelasnya dapat dilihat di Tabel 1.

Tabel 1.

Hasil Perhitungan Hasil Belajar IPA Aspek Kognitif

\begin{tabular}{|l|r|l|}
\hline Uji Mann Whitney & $105 \leq 107$ & Ho ditolak, Ha diterima \\
\hline SPSS & $0,016 \leq 0,05$ & Ho ditolak, Ha diterima \\
\hline
\end{tabular}

Metode eksperimen memilki pengaruh, dikarenakan adanya perbedaan hasil belajar IPA aspek kognitif yang signifikan. Kelompok siswa yang belajar menggunakan metode eksperimen pada kelas eksperimen memiliki rata-rata nilai 79,67, sedangkan kelompok siswa yang belajar menggunakan metode pembelajaran 
langsung pada kelas kontrol memiliki ratarata nilai 67,02. Hasil penelitian ini menunjukkan bahwa hasil belajar IPA dicapai oleh siswa yang mengikuti pembelajaran dengan metode eksperimen lebih baik dibandingkan dengan siswa yang mengikuti pembelajaran dengan metode pembelajaran langsung.

Proses pembelajaran yang dilaksanakan di kelas kontrol menggunakan pembelajaran langsung. Pembelajaran tersebut secara langsung dibimbing oleh guru, berbeda dengan proses pembelajaran di kelas eksperimen. Penggunaan metode eksperimen di kelas eksperimen membuat proses pembelajaran berpusat pada siswa (student centered) sehingga pembelajaran menjadi lebih aktif dan menarik.

Proses pembelajaran di kelas eksperimen pada pertemuan pertama yaitu dengan sistem kelompok, siswa melakukan sebuah percobaan membuat alat musik terompet. Siswa dituntut untuk memecahkan suatu masalah melalui percobaan pembuatan alat musik yang akhirnya siswa menemukan bukti kebenaran dari teori sesuatu yang sedang dipelajarinya yang selanjutnya hasil percobaan dipresentasikan oleh siswa. pembelajaran di kelas eksperimen pada pertemuan kedua sama seperti pertemuan pertama yang membedakan adalah pada pertemuan kedua tiap kelompok melakukan percobaan dengan membuat percobaan dua buah gendang sederhana yang terbuat dari kaleng bekas dan kertas semen. Siswa dituntut untuk memecahkan suatu masalah melalui percobaan pembuatan alat musik yaitu mengemukakan proses terdengarnya bunyi dari gendang sederhana. Hasil percobaan selanjutnya dipresentasikan oleh tiap kelompok.

Pembelajaran yang telah dilakukan menggunakan metode eksperimen dapat meningkatkan aspek kognittif karena sesuai dengan penjelasan dari Yogantara, dkk
(2014) bahwa melalui metode eksperimen siswa dapat melakukan percobaan langsung melalui instruksi yang disampaikan secara berurut untuk mencari jawaban terhadap permasalahan yang diajukan, sehingga siswa lebih mudah dalam memahami dan mempraktekkan apa yang telah diperolehnya. Menurut Roestiyah (2012: 80) menegaskan bahwa penggunaan metode eksperimen mendorong siswa untuk mencari dan menemukan sendiri berbagai jawaban atas persoalan-persoalan yang dihadapinya dengan mengadakan percobaan sendiri. Siswa kelas eksperimen mampu membuktikan kebenaran dan menarik kesimpulan berdasarkan percobaannya sendiri yaitu mampu mengetahui proses perubahan energi bunyi melalui penggunaan alat musik.

Pembelajaran di kelas eksperimen pada pertemuan kedua sama seperti pertemuan pertama yang membedakan adalah pada pertemuan kedua tiap kelompok membuat percobaan dua buah gendang sederhana yang terbuat dari kaleng bekas dan kertas semen. Siswa dituntut untuk memecahkan suatu masalah melalui percobaan pembuatan alat musik yaitu mengemukakan proses terdengarnya bunyi dari gendang sederhana. Hasil percobaan berupa alat musik gendang sederhana selanjutnya dipresentasikan oleh tiap kelompok

\section{Hasil Belajar IPA Aspek Afektif}

Hasil penelitian menunjukkan tidak ada pengaruh metode Eksperimen terhadap hasil belajar aspek afektif mata pelajaran IPA materi perubahan energi bunyi melalui penggunaan alat musik pada siswa kelas IV SD Negeri Sokaraja Lor.. Hal ini dibuktikan dengan hasil perhitungan dengan menggunakan uji Mann Whitney untuk mengetahui pengaruh metode eksperimen terhadap hasil belajar IPA aspek afektif. Hasil perhitungan 
menunjukkan bahwa $U_{\text {hitung }} \geq U_{\text {tabel }}$ atau 135,5 $\geq 107$; sehingga $\mathrm{H}_{0}$ diterima dan $\mathrm{H}_{\mathrm{a}}$ ditolak. Perhitungan SPSS 16,0 menguatkan hasil tersebut. Perhitungan menggunakan SPSS diperoleh nilai

signifikansi sebesar 0,123 hal ini berarti signifikasi lebih besar dari 0,05 atau 0,123 $>0,05$ yang berarti $\mathrm{H}_{0}$ diterima dan $\mathrm{H}_{\mathrm{a}}$ ditolak. Selanjutnya dapat dilihat pada Tabel 2.

Tabel 2.

Hasil Perhitungan Hasil Belajar IPA Aspek Afektif

\begin{tabular}{|l|l|l|}
\hline Uji Mann Whitney & $135,5 \geq 107$ & $\mathrm{H}_{a}$ diterima dan $\mathrm{H}_{a}$ ditolak \\
\hline SPSS & $0,123>0,05$ & $\mathrm{H}_{a}$ diterima dan $\mathrm{H}_{a}$ ditolak \\
\hline
\end{tabular}

Metode eksperimen tidak ada pengaruh terhadap hasil belajar aspek afektif dikarenakan terdapat kekurangankekurangan dalam pelaksanaan penelitian. Menurut Mustari (2011: 51) sikap kerja keras adalah perilaku yang menunjukkan upaya sungguh-sungguh dalam mengetahui berbagai hambatan guna menyelesaikan tugas (belajar/pekerjaan dengan sebaikbaiknya). Pelaksanaan penelitian pada kelas eksperimen dan kelas kontrol hanya dilaksanakan dalam 2 kali pertemuan, sementara pembentukan karakter kerja keras membutuhkan waktu yang lama dan bertahap sesuai dengan kondisi lingkungan sekitar siswa. Menurut Narwanti (2011: 5) tindakan, perilaku, dan sikap anak saat ini bukanlah suatu yang tiba-tiba muncul atau terbentuk atau bahkan given dari Yang Maha Kuasa. Hal tersebut sesuai dengan pendapat dari Ratna Megawangi (Narwanti, 2011: 5), yang menjelaskan bahwa membentuk karakter merupakan proses yang berlangsung seumur hidup.

Proses pembelajaran dilakukan dengan cara berkelompok, masing-masing siswa cenderung masih mengutamakan kepentingan sendiri-sendiri. Ada siswa yang sibuk bermain atau mengobrol dengan teman sekelompoknya, dan ada yang hanya melihat sesekali membantu. Pada saat salah satu kelompok sedang mempresentaikan hasil diskusi dan percobaan, ada beberapa kelompok lain yang tidak memperhatikan temannya yang sedang menjelaskan hasil diskusi dan percobaan. Mereka sibuk bermain dan mengobrol dengan teman sekelompoknya, sehingga tidak mencatat hal-hal yang penting saat kelompok ada yang maju presentasi. Hal-hal tersebut yang menyebabkan tidak ada pengaruh metode eksperimen terhadap hasil belajar aspek afektif.

\section{Hasil Belajar IPA Pada Aspek Psikomotor}

Hasil penelitian menunjukkan ada pengaruh metode Eksperimen terhadap hasil belajar aspek psikomotor mata pelajaran IPA materi perubahan energi bunyi melalui penggunaan alat musik pada siswa kelas IV SD Negeri Sokaraja Lor. Hal ini dibuktikan dengan hasil perhitungan dengan menggunakan uji Mann Whitney untuk mengetahui pengaruh metode eksperimen terhadap hasil belajar IPA aspek psikomotor. Hasil perhitungan menunjukkan bahwa $U_{\text {hitung }} \leq U_{\text {tabel }}$ atau $70 \leq 107$ sehingga $\mathrm{H}_{0}$ ditolak dan $\mathrm{H}_{\mathrm{a}}$ diterima. Perhitungan SPSS 16,0 menguatkan hasil tersebut. Perhitungan menggunakan SPSS diperoleh nilai signifikansi sebesar 0,001 hal ini berarti signifikasi lebih kecil 0,05 atau 0,001 < 
0,05 yang berarti Ho ditolak dan $\mathrm{Ha}$ dilihat di Tabel 3. diterima. Untuk hasil perhitungannya dapat

Tabel 3.

Hasil Perhitungan Hasil Belajar IPA Aspek Psikomotor

\begin{tabular}{|l|l|l|}
\hline Uj1 Mann Whitney & $70 \leq 107$ & $\mathrm{H}_{0}$ ditolak dan $\mathrm{H}_{\mathrm{a}}$ diterima \\
\hline SPSS & $0,001<0,05$ & $\mathrm{H}_{0}$ ditolak dan $\mathrm{H}_{a}$ diterima \\
\hline
\end{tabular}

Metode eksperimen terdapat pengaruh terhadap hasil belajar aspek psikomotor dikarenakan siswa dapat bekerjasama dengan kelompok dengan baik. Terbukti dengan siswa sudah siap dengan kegiatan yang akan dilaksanakan dan sudah menyiapkan peralatan yang akan digunakan. Selain itu, siswa mampu melaksanakan tugas sesuai dengan perintah yaitu membuat alat musik terompet dan gendang sederhana. Siswa aktif mempresentasikan hasil tugasnya yaitu masing-masing siswa dalam kelompoknya aktif mempresentasikan hasil karya alat musik yang sudah dibuat.

Proses pembelajarann dengan menerapkan metode eksperimen mampu meningkatkan kemampuan siswa dalam aspek psikomotor. Menurut Sudjana (2010: 23), ranah psikomotor berkenaan dengan hasil belajar keterampilan dan kemampuan bertindak. Siswa bersama dengan kelompoknya mampu bekerjasama dan melaksanakan tugas percobaan yang menjadikan mereka kreatif dalam mengembangkan keterampilanketerampilan yang dimiliki. Oleh karena itu, diketahui bahwa metode eksperimen memberi pengaruh terhadap hasil belajar aspek psikomotor.

\section{SIMPULAN DAN SARAN}

Berdasarkan hasil uji pengolahan data dengan uji Mann Whitney maka diperoleh aspek kognitif yaitu $U_{\text {hitung }} \leq U_{\text {tabel }}$ atau $105 \leq 107$, aspek afektif yaitu $U_{\text {hitung }} \geq U_{\text {tabel }}$ atau $135,5 \geq 107$, dan aspek psikomotor yaitu $U_{\text {hitung }} \leq U_{\text {tabel }}$ atau $70 \leq 107$. Berdasarkan hasil perhitungan di atas dapat disimpulkan bahwa terdapat pengaruh metode eksperimen terhadap hasil belajar IPA aspek kogninif dan psikomotor, tetapi tidak memberikan pengaruh terhadap hasil belajar IPA aspek afektif siswa kelas IV SD Negeri Sokaraja Lor.

Berdasarkan hasil penelitian dan simpulan maka untuk perbaikan penelitian di masa yang akan datang ada beberapa saran yang dapat disampaikan antara lain, Pembelajaran menggunakan metode eksperimen pada tahap penyusunan jadwal pelaksanaan percobaan perlu dipersiapankan secara matang, seperti memperhatikan waktu yang digunakan dalam pembelajaran. Proses pembelajaran diharapkan berlangsung efektif sehingga tidak kekurangan jam pelajaran atau melebihi jam pelajaran yang telah ditentukan, selain itu juga tugas percobaan dapat terselesaikan sesuai dengan target. Pada tahap penyelesaian percobaan dengan fasilitasi dan monitoring guru, guru harus dapat menjadi fasilitator dan membimbing siswa dalam melakukan penyelesaian percobaan agar penyelesaian percobaan dapat berjalan dengan baik. Guru harus lebih fokus membimbing siswa dan harus selalu kreatif dalam memotivasi siswa agar lebih semangat dalam menyelesaikan tugas percobaan. Cara memotivasi siswa bisa dengan memberikan penghargaan seperti pujian. Hal-hal tersebut bertujuan agar siswa memiliki sikap kerja keras dalam 
penyelesaian tugas percobaan. Pada tahap penyampaian hasil percobaan, guru harus lebih kreatif dalam membimbing dan mengarahkan siswa untuk aktif bertanya jika ada kelompok yang maju menyampaikan hasil percobaan.

\section{DAFTAR PUSTAKA}

Mustari, M. (2011). Nilai Karakter Refleksi Untuk Pendidikan Karakter. Surabaya: Laksbang

Narwanti, Sri. (2011). Pendidikan Karakter. Yogyakarta: Familia Grup Relasi Inti Media
Roestiyah N.K. (2012). Strategi Belajar Mengajar. Jakarta: Rineka Cipta. Sudjana, N. (2010). Penilaian Hasil Proses Belajar Mengajar. Bandung: PT Remaja Rosdakarya.

Yogantara, E., dkk. (2014). "Pengaruh Metode Eksperimen Terhadap Prestasi Belajar IPA Siswa Kelas IV SD Negeri Gugus IV Kabupaten Buleleng". Jurnal Mimbar PGSD Universitas Pendidikan Ganesha Jurusan PGSD. [Online], Vol 2, (1). Tersedia: [3 Agustus 2013) 